\title{
Laporan Kasus: Dentinogenesis Imperfekta
}

[Case Report: Dentinogenesis Imperfecta)

Fadli Ashar', Evellyn Islami Abdurokhman²

1 Bagian ilmu penyakit mulut, Jurusan Kedokteran Gigi, Fakultas Kedokteran

$2^{*}$ Program pendidikan profesi, Jurusan Kedokteran Gigi, Fakultas Kedokteran UNSOED

\section{Abstrak}

Dentinogenesis imperfecta adalah salah satu bentuk gangguan pertumbuhan dentin selama tahapan histodiferensiasi perkembangan gigi yang diturunkan secara herediter. Rasio angka kejadiannya adalah 1 berbanding 8000 orang. Dentinogenesis imperfekta diturunkan dengan autosomal dominan yang berefek pada gangguan pembentukan serta mineralisasi dari dentin. Seorang mahasiswi berusia 20 tahun datang ke klinik integrasi A RSGMP UNSOED dengan keluhan ingin menambal gigi nya yang patah karena menggigit kerupuk. Pasien pernah mengalami hal yang sama dengan gigi sebelahnya, dan gigi tersebut telah ditambal. Pemeriksaan intra oral menunjukkan terdapat seluruh gigi berwarna kuning kecoklatan dan translusen. Gigi anterior rahang atas dan rahang bawah mengalami atrisi. Gambaran radiografi menunjukan gambaran gigi-gigi dengan kamar pulpa menghilang dan saluran akar menyempit. Rencana perawatan yang akan diberikan adalah restorasi indirek mahkota porcelain fused to metal. Dentinogenesis imperfecta adalah kelainan yang diturunkan secara herediter yang menyebabkan gigi berwarna biru keabuan atau kuning kecoklatan, dan rapuh. Rencana perawatan yang dapat diberikan pada pasien DI adalah perawatan restoratif dapat diberikan pada gigi desidui maupun permanen, karena dentin yang terekspos akan meningkatkan resiko karies dan infeksi.

Kata kunci: Dentinogenesis imperfecta, Shield tipe II, Shield tipe III

\section{Abstract}

Dentinogenesis imperfecta is the one of most common hereditary disorder of dentin formation, especially at histodifferentiation stage. It reported have to an incidences of 1 in 8000 . Dentinogenesis imperfecta is an autosomal dominant, affecting both the formation and mineralizatin of dentin. CASE: A 20-year-old female patient came to integrasi A RSGMP UNSOED with crown fracture of anterior teeth 11, after eating a solid food. A permanent filling was conducted on 21 with the same cause one year ago. Intraoral examination showed attrition, yellowish and translucent on both maxillary and mandibullary teeths. Radiography showed that obliterated pulp chamber and shrinked root canal. Porcelain fused to metal crown was planned for this case. Conclusion: Dentinogenesis imperfecta is a hereditary disorder of tooth development. It caused the teeth to be discoloured (blve-grey or yellow-brown color), and fragile. Treatment planning for patient with dentinogenesis imperfecta is restorative treatment that can be apply to deciduous or permanent teeth, because exposed dentin will increase the risk of caries and infection.

Keywords: Dentinogenesis imperfecta, Shield tipe II, Shield tipe III

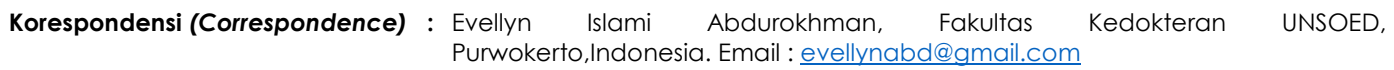

Dentinogenesis imperfecta adalah salah satu bentuk gangguan pertumbuhan dentin selama tahapan histodiferensiasi perkembangan gigi yang diturunkan secara herediter. Dentinogenesis imperfecta merupakan suatu kondisi kelainan yang diturunkan oleh gen autosomal dominan menyerang pada gigi desidui maupun gigi permanen. Dentinogenesis imperfecta (DI) termasuk kedalam localized mesodermal dysplasia dengan penampakan gigi yang transparan (opalescent) berwarna abu-abu hingga kuning kecoklatan hingga disertai dengan pembentukan dentin yang ireguler atau undermineralized juga menghilangnya kamar pulpa atau saluran akar. Dentinogenesis imperfecta (DI) dapat terlihat sendiri atau bisa juga berkaitan dengan penyakit Osteogenesis imperfecta. Anak dengan fraktur tulang tanpa penyebab dan memiliki kelainan DI bisa menjadi salah satu indikator osteogenesis imperfecta. Rasio angka kejadiannya adalah 1 berbanding 8000 orang. ${ }^{1}$
Dentinogenesis imperfecta (DI) pertama kali di klasifikasikan oleh Shields tahun 1973 terbagi menjadi 3 tipe antara lain; Tipe I yang berkaitan dengan osteogenesis imperfecta, Tipe II yang tidak berkaitan dengan osteogenesis imperfecta disebut juga hereditary opalescent dentin. Tipe III yang disebut juga brandywine type karena kejadiannya terisolir di area Southern Maryland dengan penampakan kamar pulpa yang lebar dan dinding dentin yang tipis (shell teeth). Penelitian selanjutnya menemukan bahwa Osteogenesis imperfecta tidak memiliki keterkaitan dengan dentinogenesis imperfecta. Dentinogenesis imperfecta (DI) kemudian hanya terbagi menjadi dua tipe yaitu tipe I dan tipe II dan keduanya tidak berhubungan dengan osteogenesis imperfecta. ${ }^{2}$

\section{LAPORAN KASUS}

Seorang perempuan berusia 20 tahun datang ke klinik integrasi A RSGMP UNSOED 
dengan keluhan ingin menambal gigi nya yang patah karena menggigit kerupuk. Gigi tersebut patah beberapa bulan yang lalu dan pasien hanya merasa sedikit ngilu ketika minum minuman dingin. Pasien pernah mengalami hal yang sama dengan gigi sebelahnya, dan gigi tersebut telah ditambal. Pasien mengaku tidak pernah memiliki riwayat penyakit keturunan, juga tidak pernah mengkonsumsi obat dalam jangka panjang. Pasien belum menikah dan seorang mahasiswa.

Pemeriksaan ekstra oral menunjukkan wajah simetri, warna normal, dan tidak terdapat pembesaran. Posisi mata sejajar, warna sekitar mata normal, warna sklera putih, warna kelopak mata bagian dalam merah muda dan tidak terdapat kelainan. Leher tidak terdapat pembesaran. Tangan dan jari normal, lymphonodi normal, serta temporomandibular joint (TMJ) normal. Pemeriksaan intra oral menunjukkan terdapat seluruh gigi berwarna kuning kecoklatan dan translusen. Gigi anterior rahang atas dan rahang bawah mengalami atrisi. Gigi 11 vital dengan fraktur sepertiga mahkota mencapai dentin. Gambaran radiografi menunjukan gambaran gigi-gigi dengan kamar pulpa menghilang dan saluran akar menyempit. Rasio panjang akar dan mahkota normal, tidak ditemukan lesi periapikal. Rencana perawatan yang akan diberikan adalah restorasi indirek mahkota porcelain fused to metal.

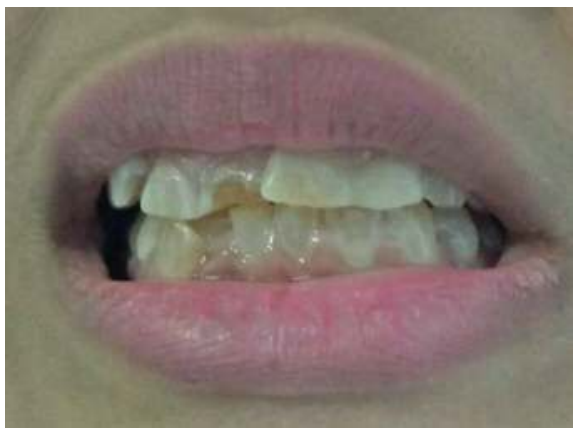

Gambar 1. gambaran klinis pasien

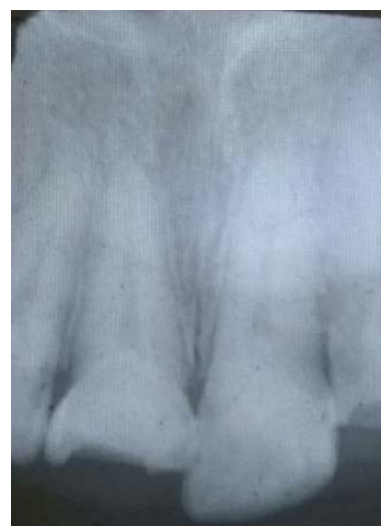

Gambar 2. gambaran radigrafi periapikal pasien

\section{PEMBAHASAN}

Dentinogenesis imperfecta setelah di revisi terbagi menjadi 2 tipe, antara lain:

1. Dentinogenesis imperfecta tipe I, yang sering disebut juga opalescent dentin, dentinogenesis imperfecta tanpa osteogenesis imperfecta, opalescent teeth tanpa osteogenesis imperfecta, dentinogenesis imperfecta, Shields tipe II, atau capdepont teeth. DI tipe ini dipisahkan dari osteogenesis imperfecta karena tidak ada peningkatan frekuensi fraktur tulang. Frekuensi kejadian DI tipe I adalah 1 berbanding 6000-8000 per kelahiran. Pada tipe ini penampakan gigi berwarna biru keabu-abuan sampai kecoklatan dan translusen. Gambaran radiografinya antara lain, bentuk gigi mahkota bulbous, akar lebih pendek, dan ruang pulpa serta saluran akar mengecil bahkan menghilang. Enamel mudah sekali fraktur atau lepas karena tekanan oklusal. 3.4

2. Dentinogenesis imperfecta tipe II, yang sering disebut juga Shields tipe III serta Brandywine type dentinogenesis imperfecta. Kelainan ini ditemukan pada Brandywine triracial yang terisolir di Southern Maryland. Mahkota gigi desidui atau gigi permanen biasanya ditemukan multiple pulp exposure. Pada gigi permanen ruang pulpa dan kamar pulpa akan mengecil sampai menghilang seiring bertambahnya umur. ${ }^{3,4}$

Dentinogenesis imperfecta disertai osteogenesis imperfecta atau Shields tipe I disebabkan mutasi gen berbeda COLIAl dan COLIA2. Produk yang dihasilkan dari gen tersebut adalah collagen tipe 1 yang berperan penting pada protein pembentuk dentin. Mutasi tersebut dapat menyebabkan DI fenotipe yang berasosiasi dengan osteogenesis imperfecta. ${ }^{4}$

Dentin memiliki komposisi 2 protein yaitu dentin phosphoprotein (DSPP) dan dentin sialoprotein (DSP). Gen yang bertanggungjawab untuk produksi DSP maupun DSPP berlokasi pada 4q12-21. DSPP akan diekspresikan pada jaringan termasuk di dalamnya yaitu tulang, ginjal, glandula salivarius, dan paru-paru, namun jumlah yang lebih banyak diekspresikan pada dentin dan jaringan lain. Protein ini membentuk 50\% komponen non kolagen dari matriks dentin. Gangguan pada sekresi protein ini akan mempengaruhi pada bentuk dan susunan dari kristal hidroksiapatit pada dentinal matriks dan terbentuklah ciri khas dari dentinogenesis imperfect tanpa disertai osteogenesis imperfecta. 4

Gambaran histologi dari dentinogenesis imperfecta murni karena adanya gangguan pada mesodermal. Penampakan enamel biasanya normal tetapi memiliki warna yang menguning atau unik khas karena adanya defek pada dentin. Gambaran pada dentin biasanya menunjukan adanya tubuli-tubuli 
dentin yang ireguler terkadang disertai area yang meluas akibat matriks yang tidak terkalsifikasi. Tubuli-tubuli dentin cenderung memiliki diameter yang lebih besar dan jumlah yang lebih sedikit dibandingkan dengan keadaan normalnya. Odontoblas tidak jarang ditemukan, tetapi kamar pulpa biasanya menghilang tergantikan oleh deposit dentin. Odontoblas biasanya memiliki kemampuan yang terbatas untuk menyusun dentinal matrix, mereka muncul kemudian degenerasi, dan terperangkap di dalam matriks. ${ }^{4}$

$$
\text { Gambaran radiografi }
$$

pada dentinogenesis imperfecta tipe 1 atau Shields tipe II, gigi tersebut memiliki mahkota bulbous dengan akar yang sedikit memendek. Kamar pulpa serta saluran akar biasanya menyempit dan terkadang menghilang. Sementara pada dentinogenesis imperfecta tipe 2 atau Shields tipe III, gambaran radiografi pada gigi desiduinya memiliki saluran akar dan ruang pulpa yang membesar pada beberapa tahun pertama dan mengecil seiring dengan pertambahan usia. Gambaran tersebut sering disebut dengan shell teeth. Secara klinis biasanya juga ditemukan beberapa pulpa yang terbuka. Sementara pada gigi permanen tipe ini biasanya memiliki gambaran radiografi berupa ruang pulpa yang mengecil bahkan menghilang seluruhnya. ${ }^{4}$

Differential diagnosis dari dentinogenesis imperfekta antara lain sebagai berikut:

1. Amelogenesis imperfekta tipe hipokalsifikasi

Amelogenesis imperfecta tipe hipokalsifikasi yang perkembangan ketebalan enamel normal tetapi memiliki kalsifikasi yang buruk sehingga enamel rapuh. Enamel pada Al tipe ini mudah atrisi dan mudah fraktur menyisakan dentin. Perbedaan lainnya dengan dentinogenesis imperfecta adalah gigi lebih sensitif dan secara radiografi enamel kurang densitasnya dibandikan dengan dentin. Kamar pulpa dan saluran akar juga terlihat normal tanpa adanya sklerotik seperti DI. ${ }^{2}$

2. Penggunaan tetrasiklin

Tetrasiklin memiliki kemampuan untuk mengikat ion kalsium yang tergabung dalam pembentukan gigi, perkembangan tulang serta kartilago, menghasilkan pewarnaan pada gigi desidui maupun permanen. Diskolorasi warna bersifat permanen dari kuning atau keabuan hingga coklat tergantung dari dosis yang dikonsumsi dan berat badan pasien. ${ }^{2}$

3. Dentin dysplasia

Dentin displasia terbagi menjadi 2 tipe, keduanya sama-sama diturunkan secara autosomal dominan seperti dentinogenesis imperfecta Shield tipe II dan III. Dentin displasia tipe I memiliki penampakan morfologi yang normal dalam bentuk maupun warna namun dibeberapa kasus terkadang terlihat translusen. Mobilitas gigi sering kali ekstrim sehingga beresiko tinggi premature loss akibat trauma kecil. Hal ini disebabkan gigi memiliki akar yang pendek. Gambaran radiografinya menunjukan pada gigi desidui memiliki akar yang pendek dan ruang pulpa serta saluran akar sering kali menghilang. Pada gigi permanen, ruang pulpa serta saluran akar terlihat seperti bulan sabit. Abses periapikal, kista radikular atau granuloma sering ditemukan karena pada tipe ini sering terjadi multiple exposure dari kamar pulpa. Sementara pada dentin displasia tipe II memiliki penampakan morfologi yang normal pada gigi desidui namun biasanya gigi berwarna translusen dan kekuningan, coklat dan abu kebiruan mirip dengan DI. Pada gigi permanen biasanya morfologi terlihat normal namun pada radiografi kamar pulpa yang besar di deskripsikan seperti gambaran thistletube karena ditemukan pulp stone. ${ }^{2}$

Rencana perawatan yang dapat diberikan pada pasien DI adalah perawatan restoratif dapat diberikan pada gigi desidui maupun permanen, karena dentin yang terekspos akan meningkatkan resiko karies dan infeksi. Perawatan pada gigi desidui yang biasa dipilih adalah stainless steel crown, dan pada gigi tetap biasanya diberikan restorasi komposit, mahkota porcelain fused to metal, maupun laminate veneer. Penggunaan jacket crown pada gigi anterior dan metal crown pada gigi posterior juga memiliki tingkat keberhasilan yang tinggi. Namun preparasinya perlu diperhatikan, serta lebih baik dilakukan pada gigi dengan panjang mahkota serta akar yang mendekati ukuran gigi normal. Perawatan restorasi direk pada gigi terkadang tidak dapat bertahan lama karena dentin yang cenderung lunak. 4,5

$$
\text { Kesimpulannya, }
$$

Dentinogenesis imperfecta adalah kelainan yang diturunkan secara herediter yang secara langsung mengganggu histodiferensiasi baik pada gigi sulung maupun gigi tetap. Dentinogenesis imperfecta terbagi menjadi 3 antara lain Shield tipe I yaitu disertai osteogenesis imperfekta, Shield tipe II tanpa disertai osteogenesis imperfekta, dan Shield tipe III atau brandywine type. Gambaran klinisnya adalah gigi berwarna biru keabuan atau kuning kecoklatan, rapuh, mudah atrisi maupun fraktur serta opalescent. Dentinogenesis imperfecta disertai osteogenesis imperfekta terjadi karena adanya mutasi gen COLIAl dan COL1A2, sementara pada dentinogenesis imperfecta tipe Shield II dan Shield III terjadi karena gangguan pada gen DSPP. Rencana perawatan yang dapat diberikan pada pasien DI adalah perawatan restoratif dapat diberikan pada gigi desidui maupun permanen. Perawatan pada gigi desidui yang biasa dipilih adalah stainless steel crown, dan pada gigi tetap biasanya diberikan restorasi komposit, mahkota porcelain fused to metal, maupun laminate veneer.

\section{DAFTAR PUSTAKA}

1. Sinha $R$, et al. Dentinogenesis imperfecta case report and literature review. Journal of oral medicine, oral surgery, oral 
pathology, and oral radiology. 2016;2(3)156-8.

2. Barron, MJ. McDonnell ST. MacKie, I. Dixon, MJ. Hereditary dentine disorder: Dentinogenesis imperfecta and Dentin dysplasia. Orphanet journal of rare diseases. 2008;3(31)1-10.

3. Langlais, RP. Color atlas of common oral diseases. Philadelphia:Lippincot William \& Wilkins. 2009.
4. Rajendran R. Sivapathasundharam B. Shafer's textbook of oral pathology. Delhi:Elsevier. 2009.

5. Bratanata O. Soehartono, AW. Auerkari, El. Manisfestasi klinis aspek genetika molekuler dan manajemen dentinogenesis imperfekta. Indonesian Journal of Dentistry.2007;14(1) 41-7 